\title{
How to Ensure Ethicality of Action Research in the Classroom?
}

\author{
Eeva-Liisa Peltokorpi \\ Maaniittu School, Nurmijärvi, Finland \\ and Faculty of Education, University of Lapland, Finland \\ Muuttolinnunreitti 26A, 02660 Espoo, Finland \\ Tel: 358-40-539-4440Ｅ-mail: peltokorpieevaliisa@gmail.com \\ Kaarina Määttä (Corresponding author) \\ Faculty of Education, University of Lapland, Finland \\ P. O. Box 122, 96101 Rovaniemi, Finland \\ Tel: 358-400-696-480Ｅ-mail: Kaarina.Maatta@ulapland.fi \\ Satu Uusiautti \\ Faculty of Education, University of Lapland, Finland \\ (May-Sep.) Lepolantie 29, 01830 Lepsämä, Finland \\ (Oct.-Apr.) 2403 SE $8^{\text {th }}$ Avenu, Cape Coral, 33990, FL, USA
}

Tel: 358-50-355-1280 / 1-239-851-6233

Received: May 4, 2012

doi:10.5430/wje.v2n3p32
Accepted: May 25, 2012

Published: June 15, 2012

\begin{abstract}
During the past few years, child research has increased both when it comes to various disciplines and various methods. The purpose of this article is to discuss those common, special ethical viewpoints that the researcher has to take into consideration when conducting action research in the classroom. The article is based on the teacher-researcher's action research which was carried out among 7-9-year-old pupils $(\mathrm{N}=21)$. The purpose was to study their emotional coping. The focus is on the following question: how to secure the children's position and voices by leaning on the principle that research should be just, valuable, and good-producing and not harm the children or have a malign influence on the phenomenon studied. The purpose is to encourage researchers to do child research and to help them pay attention to ethical challenges in the various phases of research.
\end{abstract}

Keywords: Ethics, Research with children, Action research, Primary school

\section{Introduction}

This article discusses ethical challenges in child research and is focused especially on action research conducted in schools where children are research partners. This article is based on the first author's studies on the features of action research (Peltokorpi 2007; see also Peltokorpi \& Määttä, 2010; Peltokorpi \& Määttä, 2011; Peltokorpi, Määttä, \& Uusiautti, 2011), when she studied primary school children's emotional coping and acted simultaneously as a teacher and researcher in her own classroom.

In the sample research for this article, the main research subjects were the children $(\mathrm{N}=21)$, aged between 7 and 9 , whose emotional coping was observed in the interactional classroom situations related to the mathematical problem-solving tasks during the school year 2006-2007. The researcher was an observant participator in the learning situations. The development of pupils' emotional coping within learning situations during primary school years was studied (Peltokorpi, 2007; Peltokorpi \& Määttä, 2011). The research data comprised an observational data about classroom situations, pupils' behavior, and interaction between the teacher and the pupils. Observations were complemented by children's interviews and drawings, and the researcher's diary. 
One of the main goals for this research was to enhance pupils' emotional coping to develop into emotional directedness (see Eisenberg et al., 1993), when a pupil is able to disentangle his or her emotions in a problem situation by discussing the problem with a class mate, working together, as well as struggling together to solve the problem and accomplishing the tasks. Pupils who had difficulties in interacting with their class mates were selected to participate in this research. As a result, six various forms of emotional coping were found (Peltokorpi, 2007; Peltokorpi \& Määttä, 2010).

In this article, our purpose is to answer the following question: what are the ethical challenges when conducting research with children in the classroom? What factors should be taken into account when the purpose is to carry out ethically sustainable research among children aiming at "producing good" into teaching and education in order to support pupils' learning and development? Ethical viewpoints are contemplated here from the point of view of the researcher's choices. Ethical choices in child research relate to the following themes: choosing the research theme, executing the data collection, and creating the research relationship between the adult and child. Action research necessitates a responsible role from the teacher-researcher as she or he has to be able to notice children's rights and special developmental features.

Conducting research in the classroom among children is challenging but also or primary importance. At its best, action research can enhance bringing out children's voices, their participation skills and self-expression, and affect the course of actions and thus strengthen children's position. (Powell \& Smith, 2009.)

\subsection{Action research among children}

Among others, John Dewey implemented the idea of action research already in the 1910s and 1920s when he used the term 'collaborative research'. The idea strengthened and became profounder when he noticed that pupils learn concepts, values, and interaction as well as living skills through participation and interactional action in a democratic classroom (Schmuck, 2006).

School, teaching, and learning have been studied through action research abundantly (e.g. Coll, Zegwaard, \& Lay, 2001; Coulter, 2002; Jordan \& Le Metais, 1997; Siegel, 2005). Primary school children have been studied with participative action research internationally for example by focusing on the development of classroom atmosphere and research on pupils' well-being (Kellock, 2011; Leff et al., 2011). Mohd et al. (2010) have implemented collaborative action research to affect marginalized children's mathematics learning. Furthermore, action research among children has been utilized to enhance language learning (e.g. Al-Azami, 2010).

Intellectual learning goals and social action have been developed also through action research (Al-Azami, 2010; Mohd et al., 2010; Young \& Barrett, 2001). Children's participation in action research is also studied to a great extent (Francis \& Lorenzo, 2002; Gallacher \& Gallagher, 2008). Methodological choices have given reason to study child research (Langhout \& Thomas, 2010). The methods applied in research have been quite practical-action research usually is - because its target is action and how to develop it (Heikkinen, 2006) and the happenings in everyday life (McNiff \& Whitehead, 2005). Due to this nature, the findings in action research have been direct and efficient in those settings where they have been placed (Stringer, 2004). The findings have elicited viewpoints that direct action in practice (Kiviniemi, 1999).

Action research among children sets numerous challenges to a researcher. Traditionally, children have been regarded as meaning-producing members of the society although elsewhere they have been considered merely as individuals and the diversity of child experience has been recognized (Young \& Barrett, 2001). When doing research on school, teaching, and learning, children's rights as research partners have been strongly addressed with research (Alderson, 2001; Jans, 2004; Mayall, 2000). In addition, it has been noted that child research has its own special features that differ from adult research (Altrichter et al., 2005; Punch 2002).

\subsection{Ethical principles of action research in the classroom}

The ethicality of a research has been compared with the purpose of aiming at finding moral principles that prevent from harm and injustice and promote goodness, reliability, and honesty (Sieber, 1993). Ethicality as a concept includes among other things defined moral principles and guiding/dominant rules (Morrow \& Richards, 1996). Fundamentally, child research involves discipline, professionalism, and various ways of action and thinking (Mills, 2007). Therefore, it is necessary to contemplate how to find suitable ethical working methods for the research. However, there is not just one exact answer to this question: all depends on the research context, target, and select method. (Alderson \& Morrow, 2011.)

In child research, ethicality has been dissected among other things from the perspective of children's rights (Alderson, 2001; Alderson \& Morrow, 2011; Jans, 2004; Mayall, 2000). Noticing children's rights is a part of the ethicality of the research that can be justified with the interaction between the researcher and research participant, how the researcher threats the individuals that he or she interacts with (Mills, 2007). The role of ethicality is especially important when 
using research methods that involve intimate atmosphere (see Young \& Barrett, 2001). This is also the case in action research that is carried out in the classroom by the researcher who is simultaneously the pupils' teacher. Often, the relationship between the teacher and the child - in this case, the researcher and the research subject—is extremely close (Mills, 2007).

Thus, child research involves considerably ethical tensions. Especially important is to notice the factors that relate to the selection of the research theme (Farrell, 2005; Flewitt, 2005; Ford, Sankey, \& Crisp, 2007), how representative a sample the children in that particular study make (Hill, 1997), the consequences that result from children's participation (Clark, 2005; Hill, 1997), the autonomous space given to the child in the research (Moss \& Petrie, 2002), and the data collection methods and the framework used for analyzing the data (Grover, 2004). In this article, we will discuss these factors in reference to the original study although we will not argue that we have solved these issues. However, it is important to contemplate them carefully.

\subsection{The purpose of this article}

Ethical choices are accentuated in child research because they are so heterogeneous in their sensitivity, skills, and learning abilities. Children's sensitivity is tested especially at school but on the other hand, teachers and educators know that small pupils are very apt for learning. These matters are worth realizing but they also have to be taken into account when researching children. (See Boekaerts, 1995.)

When research is carried out in the classroom by the pupils' teacher, the teacher has a great responsibility on children and he or she must not harm the pupils in any way (see Graue \& Walsh, 1998). Then, ethical questions become salient as the children act as research partners with their all sensitivity. The question is how the researcher treats individuals with whom he or she interacts.

The specific questions that we will discuss in this article are the following:

(1) What are the central conditions that direct ethical choices in action research with children as research partners?

(2) How to use action research as a data collection method among children in an ethically sustainable manner?

(3) What is the teacher-researcher's ethical responsibility when conducting research in the classroom?

\section{Results}

\subsection{What are the central conditions that direct ethical choices in action research with children as research partners?}

2.1.1 A child's participation, commitment, and withdrawal from the research

The teacher as the researcher is a decision-maker who chooses his or her own foci, defines his or her methods of data collection, analyzes and interprets the data, and develops the plan of action based on his or her analysis (Mills, 2007). Choosing the research focus or theme is sensitive in child research because it, for example, determines children's possibilities to participate in the research. When the research theme is very sensitive, plenty of obstacles to participation will occur. Sensitivity in this case may mean that the research involves some sorts of risky elements such as issues related to intimacy, stress, and religion, or the research can bring out sensitive or labeling information. When the research theme is sensitive, it widely affects the whole research process, such as ethical choices, recruiting of research participants, and research procedures. (Powell \& Smith, 2009.)

The sensitivity of the research theme is connected to the agreement to participate in research. Powell and Smith (2009) have argued that in most studies, ethical approval is the same as agreement but in child research the perspective has to be turned into children's participation and their assent. If the research can traumatize a child, it may become an obstacle to the child's participation. Minimizing this risk starts from the researcher's ethical choices that aim at increasing children's feeling of security and removing those factors that can possibly harm the children. (Powell \& Smith, 2009.)

In the research on which this article is based on, the teacher-researcher was an active actor during the research process and therefore, did not think of being an outsider or neutral. She did not assume that the class and its pupils are "somewhere" although she did rely on literature and the explanations on pupils' action provided in them. Also in teaching situations, the teacher thought of being an insider which provided her with a possibility to be in a reciprocal relationship with the pupils. This kind of participation enabled her to describe and explain the action. As a researcher, the teacher observed herself as a participant in the interaction with pupils and considered interaction as a process during which new information was produced individually and creatively. (McNiff \& Whitehead, 2006.) Stringer (2004) points out that sometimes the educator has to enter the student's world in order to understand how to create educational activities that really matter in pupils' daily life.

In the classroom, the teacher's own basic values were strongly present and it directed her action in relation to pupils. The 
teacher had to ask herself often whether the current actions were in line with the belief she appreciated. The values and need to enter the pupils' world and interactive participation in learning situations both from the teacher's and students' side functioned as a mutual promise to engage in the research. Dockett et al. (2009) employ the concepts of verbal and non-verbal interaction that represent children's consent. The request for participating in the research was not directly addressed to children although, according to studies, children are fully capable of giving their own assent (Fargas-Malet et al., 2010). In the research described in this article, the teacher-researcher thought—as Fargas-Malet et al. (2010) have pointed out - that pupils in primary education are still so small that they could not have been able to develop their emotional coping through reflection, assessment, and observation. The researcher as the teacher had to do it in a way that was possible by working together with the pupils under the teacher's guidance. Naturally, the permission for the research was asked from the children’s parents. (See Fontana \& Frey 2005; Young \& Barrett, 2001.)

The participation and commitment to the research became a natural part of the everyday life at school. The same happened with the withdrawal from the research. It was as if the pupils were riding a train where the teacher acted in various roles. At some point, the train stopped in the railhead and pupils left the train, like in the spring when the summer holiday started. With the action research, information that was supposed to improve practices was produced within a certain time period and the research and development project. The teacher carried out, according to the method of action research, a deliberate intervention in the research target, in other words the group of pupils. (Heikkinen, 2006.)

\subsubsection{Children's rights and their protection}

There is always the great danger that children are treated as a homogenous group although every child has different experiences and points of view, and they might have quite a deep understanding about the matters in the surrounding life (see Dockett et al., 2009). When it comes to child research, children's rights have been of great interest and many kinds of argumentations are expressed about participative studies aimed at children. The concept of rights is derived from the effect of the society and its conformance with the law. The society produces certain kinds of citizens' and children's rights which may appear in the field of social sciences so that researchers may become encouraged to use more participatory approaches in their studies. As children's societal rights seemingly hint of their ethical and moral excellence, the researcher may find it difficult to regard participatory research with criticism. It is not possible that the participatory research is able to produce the best research data, results, and even commit to the research within the atmosphere of this kind of ethical and moral excellence. (Gallacher \& Gallagher, 2008; see also Holland et al., 2008; Nind, 2011.)

In child research, attention is naturally paid on children's rights which in practice may appear as giving the children mandates to decide about themselves and their action. The question is about the researcher's ethical choices. Methodological reflection, ethical choices and related decisions guided the researcher see the power in children's action. The child is no longer a research target "possessed" by the adult but a participative actor. This kind of sharing strengthens children's skills and self-esteem. (Gallacher \& Gallagher, 2008; Powell \& Smith, 2009.) But how does this appear in practice? Can children really be participative actors in a research?

In the sample study of this article, children could participate in the actual doing and express their opinions and willingness to participate. Yet, the practical reality in the school world regrettably often dictates the methods that a researcher can use. In the research described in this article, the teacher acted simultaneously both as the researcher and the children's teacher. The pupils were selected based on the research data, observation, and interviews. Dockett et al. (2009) warns about this kind of action because the teacher's presuppositions may even prevent a child's participation. These conclusions may be based for example on a child's mental skills or the teacher's assumption that the pupil is unsuitable for the group. McNiff and Whitehead (2005) point out that the researcher has to consider the fact that it is impossible to stay on the research path completely if he or she conducts the research by himself or herself. The researcher has to be selective and choose for example such two or three participants who represent the core of the research theme at that moment; in other words, the researcher has to select pupils who differ in their skills and thus represent other pupils as well. On the other hand, it is reasonable to ask how children's dissimilarity is recognized in the research if all who are willing are not allowed to participate. Do we assume that some children speak for all children? (Dockett et al., 2009.) The third question could be "what is a child's voice and how do we listen to it" (Davis 1998)?

Research that is focused on children may represent a process of understanding dissimilarity. The process involves questions that relate to ethicality as well as those roles and tools that are used when studying children. The strong base for the research is built with the methods the researchers select and their academic and personal assumptions that concern each research area. When it comes to child research, it is essential that the researcher defines the research according to the purpose of learning about children's own culture. It means that the research contains various proportions of children's voices and reflection which emerges from the researcher being present in children's world. (Davis, 1998.) 
The ethics in child research can be divided into three main categories: informed consent, confidentiality, and protection. Informed consent is connected to the research approaches created by adults or researchers and that respect children and treat them justly and honestly. Research has shown that in child research, the relationship between the researcher and children is powerful containing various power structures. (Morrow \& Richards, 1996.) Therefore, the researcher has the ethical responsibility to share children's feelings during the research (Levin, 1994). The researcher should be aware that the child may have doubts about his or her success or low self-esteem (Davis, 1998). The adult's power manifests itself in research so that the researcher uses techniques that allow children to feel being a part of the research process (Morrow \& Richards, 1996).

\subsubsection{The power imbalance between the child and the adult in a research}

Previously children were considered merely as research targets than conscious social actors (see Kellett \& Ding, 2004; Mauthner, 1997). A child as an individual can be seen in the research in a variety of ways. The child can be regarded as similar to an adult who can be studied with methods used for adult research (James et al., 1998). The child can also be considered different from an adult, a competent person (Alderson, 1995), although Morrow (1999) states that, in that situation, the power relationship between the adult and child is not equal. The third way of perceiving the child is, according to Fargas-Malet et al. (2010), to regard the child as an adult but with different competences. On the other hand, it is obvious that children differ from adults. Children have a different way of using words and vocabulary than adults. Children understand words differently than adults. All this is presumably related to the fact that children's lived life is still so short that they have less life experience than adults do. (Boyden \& Ennew, 1997.) Furthermore, it is difficult to claim that research can be conducted in the same way with fife-year-old children than with sixteen-year-olds. Although developmental reasons may explain older and younger children's differences, those justifications should be regarded with criticism. It is worth noticing that children's developmental patterns are not universal but socially and culturally specific. (Woodhead, 1998.) In this research, the teacher was aware of the imbalance between her and the children but by adopting the researcher's role she was capable of becoming an active participant in children's life and considering children as capable research participants, downright research partners.

\subsection{How to use action research as a data collection method among children?}

It is essential that the researcher evaluates the research method and techniques how they could induce children's voices to become audible. Methodological choices, ethical practices, and data analysis and interpretation should be made visible through children's voices. (See Fargas-Malet et al., 2010.) In the research on which this article is based, the data were collected through observations, interviews, pupils' drawings, and the teacher's research diary. Various methods were utilized because children are not necessarily familiar with all methods that are commonly used in social sciences. Various techniques should be employed in child research because every child has their own kind of expertise of the phenomenon under research. Some children can express themselves for example better by drawing than speaking.

\subsubsection{Direct observation}

One data collection method in the sample research of this article was direct observation. The clear advantage of it is that the researcher can acquire first-hand information in relation to the research subject. The method was chosen because it enabled the researcher to collect research data from the real-life situation which cannot be acquired from secondary sources. (Tomal, 2003.) The observation method has a long tradition in small children research (Clark, 2005) and developmental-psychological studies (Hill, 1997). As the researcher was the teacher to her class in the learning situation, she was sometimes obliged to leave an interesting pupil-to-pupil conversation to guide other pupils who needed help. The researcher was an observant participant in the learning situation because the pupils needed her primarily as their teacher. Schmuck (2006) refers to this kind of action with the term 'observant participation'. It covers listening, watching, reflecting, and engaging in the discussion with pupils (Mayall, 2000). Punch (2002) considers observation and various questionnaires traditional methods that are not participatory methods. In the research illustrated here, the methods were chosen based on the fact that various methods and techniques can be employed when researching children. What is more crucial is that the select methods and procedures are reflected in a critical manner. (Barker \& Waller, 2003; Fargas-Malett et al., 2010; Sanders \& Munford, 2005.)

The researcher had two roles which is actually quite usual in child research (Cossaro, 1985; Fine, 1987; Fine \& Sandström, 1988; Mandell, 1991). Yet, diverging opinions exist concerning how these roles allow the researcher be in interaction with children during the research (Morrow \& Richards, 1996). Some researchers think that adults can do research by adopting only the researcher's role because adults' and children's worlds are so different. In addition, their age and authority hinder them to fully participate in children's world (see Goode, 1986; Mandell, 1991). Furthermore, adults are claimed to be unable to participate in children's social world because in reality they are not children ever again (Fine \& Sandstrom, 1988; Hill, 1997). The teacher in the research of this article was bold when adopting the researcher's role through which she was capable of becoming an active participant in children’s life (Morrow \& Richards, 1996). 


\subsubsection{Interviews and drawings}

There are various reasons for using drawings when studying small children. In the research of this article, children told about their opinions and experiences by drawing. The teacher-researcher had noted that drawings make a good means of analyzing difficult issues and they can help the child to relax and may trigger off the conversation. (Hill, 1997; Miles, 2000.)

Baresford (1997) thinks that interviewing is one of the best methods when it is executed in the context of daily life. The pupils were supposed to express their opinions and perceptions in interviews that were planned to function as a support to deciphering the research theme (Tomal, 2003). Interview questions were designed in a child-friendly spirit to be suitable for small children (Fargas-Malett et al., 2010) and facial expressions were used in the questionnaire in order to make answering easier for children (Clark, 2005). Verifiably, children seem to find answering this kind of questions easier on paper than in face-to-face contact. On the other hand, it has been claimed that small children do not find choosing a relevant response easy. (Hill, 1997.)

\subsubsection{The teacher's diary}

In her diary, the teacher made notes about pupils' talk as such. In practice, it went well because direct observation implemented in this research is a practical method that, according to Tomal (2003) is easily convertible into an anecdotal form. When anecdotal notes are made in the classroom, the key factor is fast observation on the important behavior which is relevant to the research (see McNiff \& Whitehead, 2005).

Children have to be informed about the research and they have to be helped understand the nature of the research: what will happen, what are they expected to do, what happens to the research data, and for what the research results are used. Carrying out research is challenging and ethically suspicious if children are not told what the research involves. Even previous experiences or knowledge do not diminish the need for informing children. (Dockett et al., 2009.) In the research of this article, the pupils knew that the teacher acted as a researcher and as a teacher in the learning situations. At first, they used to ask the teacher: "hey teacher, what are you writing in there?" As the research process moved on, the children stopped asking and paying attention to it-even if the teacher stood next to the group or pair of pupils taking shorthand about pupils' action. However, the teacher did not notice that the pupils would have acted in those learning situations differently than in other lessons. Tomal (2003) warns about this. When people get plenty of attention, they are more motivated to perform better; that is the so-called Hawthorne effect. Thus, the researcher should minimize participants' awareness of participating in the research; and thus, the teacher tried to set up as natural environment as possible to the research (see Tomal, 2003) and the learning situations were similar to any ordinary math lessons in the week schedule.

\subsection{The central issues along the research process}

The research described in this article was ignited by the teacher-researcher's professional developmental needs that were focused on pupil-centered issues. The teacher's antennae had sensed something in the classroom that worried her and she wanted to intervene in the situation with research. Her concern gave the impetus for starting the research and simultaneously it motivated the teacher to engage in it. She had to face the complex world of the classroom where she was able to step in with the method of action research. (Tomal, 2003.) At its best, action research combines the teacher's and researcher's roles and introduces theoretical knowledge to support educational work (Linnansaari, 2004). Furthermore, teacher's professionalism develops when she reflects the practices systematically (Mills, 2007).

\subsubsection{Reflection, analysis, and interpretation}

According to Leino (1996), the key concept of action research is reflection where the main element is the deliberation of action more deeply than just on the familiar action level. Schmuck (2006) writes on the initial pages of Practical Action Research for Change that during action research, the researcher learns to practice reflective thinking and to understand better the situations he or she has encountered and to prepare himself or herself to take action in a new way. Reflection is a dialogue between questions and answers that the researcher does by himself of herself. The researcher tries to answer the questions: what I have learned from this research, what the basis of my learning is, and what I should do now. (Altrichter et al., 2005; Mills, 2007.) The role of an action researcher involves high-level reflectivity and sensitivity; they are also factors through which the whole process of action research progresses. The researcher may understand himself or herself better through interactive, inner thinking that together with professionalism molds the researcher's identity. (Somekh, 2006.) Reflective sensitivity may function otherwise as well. When the researcher reflects his or her action profoundly and the grasp of the core concept of the research can sometimes slip in a manner of speaking. One has to place it again of the palm of one's hand in order to have a look at it from the front, back, and sides, and possibly inside, too. 
In the research described in this article, deep learning resulted from combining reflection and practice (Somekh, 2006). At the same time, the researcher's self-comprehension developed which is particularly important in action research because data analysis and the process of interpreting the significance of development happens through the researcher's self which also functions as the research instrument. The development of self-comprehension improved the quality of research so that the researcher began to realize how individual factors, values, and presumptions molded the research results. Alongside reflection, the researcher analyzed the research data continuously although Mills (2007) warns the researcher from doing premature action-based analysis and interpretation of data. On the other hand, carrying out data analysis was necessary for the action, not to mention for the progress of the research. This kind of action also required decisions in order to move on with the research in line with the research questions. Unfortunately, inexperienced action researchers often make hasty or impulsive decisions that are grounded on scarce or non-existent data (Mills, 2007). Sometimes making significant decisions was challenging because there was a danger of interpreting children's answers and other factors in the research out of their context (Dockett et al., 2009). The researcher had to make sure that she did not direct children's action in the frames of adults' control and guidance (Annot \& Reay, 2007).

\subsubsection{Reporting the results}

The researcher is responsible for the research from the beginning and that responsibility covers ethical choices as well. One problem in ethicality relates to the fact how truthfully the researcher reports the results (see Fontana \& Frey, 2005). The researcher must present those interpretations and conclusions that the results give reason for as rigorously as possible. Specifically, the interpretation part should be as scarce and non-speculative as possible. Deduction should be based on those facts that the research elicited. Interpreting the results is the researcher's privilege and responsibility. Heikkilä (2002) considers it a moral demand that the researcher has to hold on to.

In our sample research, the teacher-researcher tried to be as honest as possible when reporting the results. She knew that careful reporting and describing the execution of the research and observations would improve the reliability of the research. (Hirsijärvi et al., 2004.) Therefore, the teacher-researcher made detailed notes during the whole research process after which she compiled the notes of pupils' action and speech into a form of a table in order to convince the readers about the truthfulness of the research. The table also helped the researcher to categorize the pupils' communication in learning situations. She complemented the data with the pupils' drawings because she expected them to improve the reliability of the research. The drawings illustrate the reality where the research was implemented. The researcher assumed that describing and explaining the research in detail would give the reader an insight of the participants' original experiences and bring out the pupils' voices. Moreover, she thought that the reader could sense the similarity between the researcher's and participants' experiences. (See Perttula, 1995.)

\subsection{What is the teacher-researcher's ethical responsibility when conducting research in the classroom?}

A teacher who studies children should choose such a data collection method that will not harm children psychologically or emotionally (Alderson \& Morrow, 2011; Fontana \& Frey, 2005; Tomal, 2003) or make children feel anxious in any way (Alderson \& Morrow, 2011). Neither should the method affect the pupils' learning environment in the classroom negatively (Tomal, 2003). The researcher's fears, expectations, prejudices, and opinions on children may have an influence on methodological choices (James et al., 1998). It is possible for example when the question is about researching people or issues that are close to the researcher (see Young \& Barrett, 2001).

When the research is directed systematically and in a disciplined manner, the individual prejudices on research results are minimized. However, if a teacher studies the action of his or her own pupils, he or she will be part of the action and thus disciplined action is often difficult. According to Mills (2007), in informal and intimate activities-what the classroom research presumably is - it is challenging to leave objectivity and look at the mirror and reflect the visible results (see also Young \& Barrett, 2001). Mills goes on by saying that it is easy to collect data that only supports the existing practice and therefore controls the prevailing situation and does not detach researchers from their collective base; ignoring the inconsistent data or unreliable research results. This may also be the case of literature review because the researcher may select literature that he or she wishes to support. Mills (2007) concludes that none of the above-mentioned actions is acceptable in research: one should not adjust the data collection according to one's prejudices.

Research has shown that if children do not produce reliable research data, it will not be the children's fault but the grown-up way of taking the children (Alderson, 1995). Connolly (1998) has stated that problems occur at once when a child is being critically reflective and questions your role as a researcher and your relationship with the research objects. When the research is focused on children, a particular ethical challenge concerns the way how the child's role is perceived in the research. The following question should be considered: Does the researcher produce a living theory that wells from the descriptions and explanations of practical work and where the child participates voluntarily and not as 
adjusted in some kind of model? And if individuals do not fit in the model, have they failed somehow? (See Whitehead \& McNiff, 2006.)

Studies about early childhood are directed in listening to children's voices and they pay attention to children as active social members of the culture (Dockett et al., 2009). Listening to children's voices and bringing them out in research results may - at its simplest — be done by reporting carefully what was done together with children during the research. In our sample research, one research method was interview which was specifically designed for children so that the children would find it easy to answer the questions. In the interviews, the children's experiences were enquired after (see Scott, 2000) and they could answer shortly by choosing suitable facial expressions (see Dockett et al., 2009). The researcher did not consider the responses irrelevant although the children's answers were short (see Morgan et al., 2002). The children were regarded as social actors who are capable of making decisions and influence their lives and structures of their childhood (Greene \& Hill, 2005; James et al., 1998). In this way, the view was bent on the children's way of perceiving and analyzing the world (Thomas \& O'Kane, 1998).

\section{Discussion}

Research discourse has focused increasingly on the ethicality of research as the question on how children differ from others as research targets has been deliberated (Morrow, 2008). The ethicality-related demands place a teacher in a challenging task when implementing research in his or her own classroom. Then, the teacher is both a teacher and a researcher and balancing between the roles brings its own challenges. What is essential in the research process is to treat pupils in an ethically correct manner which may be difficult as the relationship between the teacher and pupils is often so close. (Mills, 2007.)

Studies have shown that children are not in the same position as adults in the society. Children are under adults' guidance and therefore they have fewer possibilities to influence their life. Although the teacher worked in school where the teacher's position in relation to children may be even quite authoritative, her ethical responsibility did not direct her to consider children only as passive adult-dependent research objects but competent social actors who affect their life actively (see Barker \& Waller, 2003).

The teacher-researcher informed the children about the nature of the research, its phases, expectations placed on children, the usefulness of the data, and how the results will be used (Dockett et al., 2009). She expressed things with a simple language and used methods suitable for children. The quality of information is important for ethicality and it is emphasized especially in research conducted with children. (Bogolub \& Tohomas, 2005.) In school-related research, children's participation in the research has to go via adults and the careful information the teacher provides the children with is an outcome of thorough ethical deliberation (see Morrow, 2008).

Action research as an approach seemed to respect and strengthen the children's own participation in the research. The methods utilized during the research treated justly the children who participated in the research (see Morrow \& Richards 1996). Stable and deep interaction between the children and the teacher was transmitted in the research report which was compiled from rigorous descriptions, illustrations, and tables. At the same time, children's voices started to become audible making the researcher's voice to fade away almost completely.

\section{References}

Al-Azami, S., Kenner, C., Ruby, M., \& Gregory, E. (2010). Transliteration as a bridge to learning for bilingual children. International Journal of Bilingual Education and Bilingualism, 13(6), 83-700. http://dx.doi.org/10.1080/13670050903406335

Alderson, P. (2001). Research by children: rights and methods. International Journal of Social Research Methodology: Theory and Practice, 4(2), 139-153. http://dx.doi.org/10.1080/13645570120003

Alderson, P., \& C. Goodey (1996). Research with disabled children: how useful is child-centred ethics? Children \& Society, 10, 106-116. http://dx.doi.org/10.1002/(SICI)1099-0860(199606)10:2<106::AID-CHI18>3.0.CO;2-V

Alderson, P., \& Morrow, V. (2011). The ethics of research with children \& young people: a practical handbook. London: Sage.

Altrichter, H., Posch, P., \& Somekh, B. (2005). Teachers investigate their work. An introduction to the methods of action research. London: Taylor \& Francis e-library.

Barker, J., \& Waller, S. (2003). "Never work with children": the geography of methodological issues in research with children. Qualitative Research, 3(2), 207-227. http://dx.doi.org/10.1177/14687941030032004 
Boekaerts, M. (1995).The interface between intelligence and personality as determinants of classroom learning. In D.H. Saklofske \& M. Zeidner (Eds.), International handbook of personality and intelligence (pp. 161-183). New York, NY: Plenum Press.

Bogolub, E. B., \& Tohomas, N. (2005). Parental consent and the ethics of research with foster children: beginning a cross-cultural dialogue. Qualitative Social Work, 4(3), 271-92. http://dx.doi.org/10.1177/1473325005055592

Boyden, J., \& Ennew, J. (Eds.) (1997). Children in focus: a manual for experiential learning in participatory research with children. Stockholm: Rädda Barnen.

Clark, A. (2005). Listening to and involving young children: a review of research and practice. Early Child Development \& Care, 175(6), 489-505. http://dx.doi.org/10.1080/03004430500131288

Coll, R. K., Zegwaard, K., \& Lay, M. (2001). The influence of cooperative education on student perceptions of their ability in practical science. Journal of Cooperative Education, 36(3), 58.

Connolly, P. (1998). Racism, gender identities and young children: social relations in a multi-ethnic, inner-city primary school. London: Routledge.

Coulter, D. (2002). What counts as action in educational action research. Educational Action Research, 10(2), 189-206. http://dx.doi.org/10.1080/09650790200200181

Davis, M. (1998). Understanding the meanings of children: reflexive process. Children \& Society, 12, 325-335. http://dx.doi.org/10.1111/j.1099-0860.1998.tb00089.x

Dockett, S., Einarsdottir, J., \& Perry, B. (2009). Research with children: Ethical tensions. Journal of Early Childhood Research, 7(3), 283-298. http://dx.doi.org/10.1177/1476718X09336971

Eisenberg, N., Fabes, R. A., Bernzweig, J., Karbon, M., Poulin, R., \& Hanish, L. (1993). The relations of emotionality and regulation to preschoolers' social skills \& sociometric status. Child Development, 5(63), 1418-1438. http://dx.doi.org/10.2307/1131543

Fargas-Malet, M., McSherry, D., Larkin, E., \& Robinson, C. (2010). Research with children: Methodological issues and Innovative techniques. Journal of Early Childhood Research, 8(2), 175-192. http://dx.doi.org/10.1177/1476718X09345412

Farrell, A. (2005). Ethical research with children. New York, NY: Open University Press.

Fine, G. A. (1987). With the boys. Chicago, IL: University of Chicago Press.

Fine, G. A., \& Sandström, K. L. (1988). Knowing children: participant observation with minors. Thousand Oaks, CA: Sage.

Flewitt, R. (2005). Conducting research with young children: some ethical issues. Early Childhood Development \& Care, 175 (6), 553-565. http://dx.doi.org/10.1080/03004430500131338

Fontana, A., \& Frey, J. H. (2005). The interview. From neutral stance to political involvement. In N. K. Denzin \& Y. S. Lincoln (Eds.), The handbook of qualitative research (pp. 695-728). London: Sage.

Ford, K., Sankey, J., \& Crisp, J. (2007). Development of children's assent documents using a child-centred approach. Journal of Child Health Care, 11(1), 19-28. http://dx.doi.org/10.1177/1367493507073058

Francis, M., \& Lorenzo, R. (2002). Seven realms of children's participation. Journal of Environmental Psychology, 22, 157-169. http://dx.doi.org/10.1006/jevp.2001.0248

Gallacher, L.-A., \& Gallagher, M. (2008). Methodological immaturity in childhood research? Thinking through participatory methods. Childhood, 15(4), 499-516. http://dx.doi.org/10.1177/0907568208091672

Goode, D. A. (1986). Kids culture and innocents. Human Studies, 9, 83-106. http://dx.doi.org/10.1007/BF00142911

Graue, E. M., \& Walsh, D. J. (1998). Studying children in context: Theories, methods and ethics. Thousand Oaks, CA: Sage.

Greene, S., \& Hill, M. (2005). Researching children's experience: methods and methodological issues. In S. Greene \& D. Hogan (Eds.), Researching children's experience: Approaches and methods (pp. 1-21). London: Sage.

Grover, S. (2004). Why won't they listen to us? On giving power and voice to children participating in social research. Childhood, 11 (1), 81-93. http://dx.doi.org/10.1177/0907568204040186 
Heikkilä, M. (2002). Eettisiä ongelmia yhteiskuntatieteellisessä tutkimuksessa [Ethical problems in social science research]. In S. Karjalainen, V. Launis, R. Pelkonen, \& J. Pietarinen (Eds.), Tutkijan eettiset valinnat [Researcher's ethical choices] (pp. 165-176). Tampere: Gaudeamus.

Heikkinen, H. L. T. (2006). Toimintatutkimuksen lähtökohdat [The basis of action research]. In H. L. T. Heikkinen, E. Rovio, \& L. Syrjälä (Eds.), Toiminnasta tietoon. Toimintatutkimuksen menetelmät ja lähestymistavat [From action to information. The methods and approaches of action research] (pp. 16-38). Vantaa: Dark Ltd.

Hill, M. (1997). Participatory research with children. Research Review. Child \& Family Social Work, 2, 171-183. http://dx.doi.org/10.1046/j.1365-2206.1997.00056.x

Hirsijärvi, S., Remes, P., \& Sajavaara, P. (2004). Tutki ja kirjoita [Research and write]. Helsinki: Tammi.

Holland, S., Renold, E., Ross, N., \& Hillman, A. (2008). Rights, "right on" or the right thing to do? a critical exploration of young people's engagement in participative social work research. NCRM Working Paper Series 07/08. [Online] available: http://eprints.ncrm.ac.uk/460/

James, A., Jenks, C., \& Prout, A. (1998). Theorizing childhood. Cambridge: Polity Press.

Jans, M. (2004). Children as citizens. Towards a contemporary notion of child participation. Childhood, 11(1), 27-44. http://dx.doi.org/10.1177/0907568204040182

Jordan, D., \& Le Metais, J. (1997). Social skilling through cooperative learning. Educational Research, 39(1), 3-21. http://dx.doi.org/10.1080/0013188970390101

Kellett, M., \& Ding, S. (2004). Middle childhood. In S. Fraser, S. Lewis, S. Ding, M. Kellet, \& C. Robonson (Eds.), Doing research with children and young people (pp. 161-174). London: The Open University.

Kellock, A. (2011). Through the lens: accessing children's voices in New Zealand on well-being. International Journal of inclusive Education, 15(1), 41-55. http://dx.doi.org/10.1080/13603116.2010.496194

Kiviniemi, K. (1999). Toimintatutkimus yksilöllisenä prosessina [Action research as an individual process]. In H. L. T. Heikkinen, R. Huttunen, \& P. Moilanen (Eds.), Siinä tutkija missä tekijä. Toimintatutkimuksen perusteita ja näköaloja [There's a researcher where is an actor. The basics and prospects of action research] (pp. 63-83). Jyväskylä: Atena.

Langhout, D. R., \& Thomas, E. (2010). Imaging participatory action research in collaboration with children: an introduction. American Journal of Community Psychology, 46, 60-66. http://dx.doi.org/10.1007/s10464-010-9321-1

Leff, S., Thomas, D., Shapiro, E., Paskewich, B., Wilson, K., Necowitz-Hoffman, B., \& Jawad, A. (2011). Developing and validating a new classroom climate observation assessment tool. Journal of School Violence, 10(2), 165-184. http://dx.doi.org/10.1080/15388220.2010.539167

Leino, J. (1996). Toimintatutkimus: Käytännön ja tutkimuksen yhdistäjä [Action research: Combining practice \& research]. In S. Ojanen (Ed.), Tutkiva opettaja 2 [Teacher as researcher 2] (pp. 81-90).Tampere: Tammer-Paino.

Levin, I. (1994). Children's perceptions of their families. In J. Brannen \& M. O’Brien (Eds.), Childhood \& Parenthood. London: Institute of Education University of London.

Linnansaari, H. (2004). Toimintatutkimus - tutkimus muutoksen palveluksessa [Action research - research to serve change]. In P. Kansanen \& K. Uusikylä (Eds.), Opetuksen tutkimuksen monet menetelmät [Researching teaching with many methods] (pp. 113-129). Juva: WS Bookwell.

Mandell, N. (1991). The least adult role in studying children. In F. C. Waksler (Eds.), Studying the social worlds of children: sociological readings (pp. 38-59). London: Falmer Press.

Mauthner, M. (1997). Methodological aspects of collecting data from children. Children \& Society, 11, 16-28. http://dx.doi.org/10.1111/j.1099-0860.1997.tb00003.x

Mayall, B. (2000). The sociology of childhood in relation to children's rights. The International Journal of Children's Rights, 8, 243-259. http://dx.doi.org/10.1023/A:1011268427242

McNiff, J., \& Whitehead, J. (2005). Action research for teachers. A practical guide. London: David Fulton Publishers.

Mills, G. E. (2007). Action research. A guide for the teacher researcher. Upper Saddle River, NJ: Merrill/Prentice Hall. 
Mohd, M., Halim, S., Rahman, L., Abdullah, S., Tan, R., Halimah, H., Arbaat, H., \& Abang, I. (2010). Teaching marginalized children. Primary science teachers' professional development through collaborative action research. Cypriot Journal of Educational Sciences, 5(1), 26-38.

Morgan, M., Gibbs, S., Maxwell, K., \& Britten, N (2002). Hearing children's voices: methodological issues in conducting focus groups with children aged 7-11 years. Qualitative Research, 2(5), 5-20. http://dx.doi.org/10.1177/1468794102002001636

Morrow, V. (2008). Ethical dilemmas in research with children and young people about their social environments. Children's Geographies, 6(1), 49-61. http://dx.doi.org/10.1080/14733280701791918

Morrow, V., \& Richards, M. (1996). The ethics of social research with children: an over view. Children \& Society, 10, 28-40. http://dx.doi.org/10.1002/(SICI)1099-0860(199606)10:2<90::AID-CHI14>3.0.CO;2-Z

Moss, P., \& Petrie, P. (2002). From children's services to children's spaces. London: Routledge Falmer.

Nind, M. (2011). Participatory data analysis: a step too far? Qualitative Research, 11(4), 349-363. http://dx.doi.org/10.1177/1468794111404310

Peltokorpi, E.-L. (2007). Yhtä kaikki yksinäisen - Tutkimus alkuopetuksen oppilaiden emotionaalisesta hallinnasta [No child is an island - A study of emotional coping among primary pupils]. (Acta Universitasis Lapponiensis 124.) Rovaniemi: University of Lapland.

Peltokorpi, E.-L., \& Määttä, K. (2010). The pupils' emotional coping in the mathematics lessons in the primary school. Cypriot Journal of Educational Sciences, 5(4), 282-295.

Peltokorpi, E.-L., \& Määttä, K. (2011). How does the pupils’ emotional coping develop within learning situations during primary school years? Europe's Journal of Psychology, 7(2), 295-322. http://dx.doi.org/10.5964/ejop.v7i2.131

Peltokorpi, E.-L., Määttä, K., \& Uusiautti, S. (2011). Children as teacher-researcher's research partners - Action research in the classroom. British Journal of Educational Research, 1(1), 18-35.

Perttula, J. (1995). Kokemus psykologisena tutkimuskohteena: Johdatus fenomenologiseen psykologiaan [Experience as psychological research target: An introduction to phenomenological psychology]. Tampere: Finnish Phenomenological Institution.

Powell, M., \& Smith, A. (2009). Children's participation rights in research. Childhood, 16(1), 124-142. http://dx.doi.org/10.1177/0907568208101694

Punch, S. (2002). Research with children: the same or different from research with adults? Childhood, 9(3), $321-341$.

Sanders, J., \& Munford, R. (2005). Activity and reflection: research and change with diverse groups of young people. Qualitative Social Work, 4(2), 197-209. http://dx.doi.org/10.1177/1473325005052393

Schmuck, R. A. (2006). Practical action research for change. Thousand Oaks, CA: Corwin Press.

Scott, J. (2000). Children as respondents. The challenge for quantitative methods. In P. Christensen \& A. James (Eds.), Research with children. Perspectives \& practices (pp. 98-119). London: RoutledgeFalmer.

Sieber, J. (1993). The ethics and politics of sensitive research. In C. Renzetti \& R. M. Lee (Eds.), Researching sensitive topics (pp. 14-26). London: Sage.

Siegel, C. (2005). An ethnographic inquiry of cooperative learning implementation. Journal of School Psychology, 43(3), 219-239. http://dx.doi.org/10.1016/j.jsp.2005.04.005

Somekh, B. (2006). Action research: a methodology for change and development. Berkshire: Open University Press.

Stringer, E. (2004). Action research in education. New Jersey, NJ: Merrill/Prentice Hall.

Thomas, N., \& O’Kane, C. (1998). The ethics of participatory research with children. Children \& Society, 12, $336-48$. http://dx.doi.org/10.1111/j.1099-0860.1998.tb00090.x

Tomal, D. R. (2003). Action research for educators. Lanham: Scarecrow Education.

Woodhead, M. (1998). Children's perspectives on their working lives: a participatory study in Bangladesh, Ethiopia, The Philippines, Guatemala, El Salvador \& Nicaragua. Stockholm: Rädda Barnen.

Young, L., \& Barrett, H. (2001). Adapting visual methods: action research with Kampala street children. Area, 33(2), 141-152. http://dx.doi.org/10.1111/1475-4762.00017 